Article

\title{
Excavatoids E and F: Discovery of Two New Briaranes from the Cultured Octocoral Briareum excavatum
}

\author{
Ping-Jyun Sung ${ }^{1,2,3, *}$, Bo-Yuan Chen ${ }^{1,2}$, Mei-Ru Lin ${ }^{2,3}$, Tsong-Long Hwang ${ }^{4}$, \\ Wei-Hsien Wang ${ }^{2,3}$, Jyh-Horng Sheu ${ }^{3}$ and Yang-Chang $\mathrm{Wu}^{5, *}$
}

1 Graduate Institute of Marine Biotechnology and Department of Life Science and Graduate Institute of Biotechnology, National Dong Hwa University, Checheng, Pingtung 944, Taiwan;

E-Mail: chenpau10205@hotmail.com (B.-Y.C.)

2 National Museum of Marine Biology \& Aquarium, Checheng, Pingtung 944, Taiwan;

E-Mails: linmeiru@hotmail.com (M.-R.L.); whw@nmmba.gov.tw (W.-H.W.)

3 Department of Marine Biotechnology and Resources and Asia-Pacific Ocean Research Center, National Sun Yat-sen University, Kaohsiung 804, Taiwan;

E-Mail: sheu@mail.nsysu.edu.tw (J.-H.S.)

4 Graduate Institute of Natural Products, Chang Gung University, Taoyuan 333, Taiwan; E-Mail: htl@mail.cgu.edu.tw (T.-L.H.)

5 Graduate Institute of Natural Products, Kaohsiung Medical University, Kaohsiung 807, Taiwan

* Authors to whom correspondence should be addressed; E-Mails: pjsung@nmmba.gov.tw (P.-J.S.); yachwu@kmu.edu.tw (Y.-C.W.).

Received: 26 August 2009; in revised form: 19 September 2009 / Accepted: 23 September 2009 / Published: 23 September 2009

\begin{abstract}
Two new briarane-related diterpenoids, designated as excavatoids E (1) and F (2), were isolated from the cultured octocoral Briareum excavatum. The structures of compounds 1 and 2 were established on the basis of extensive spectral data analysis. Briaranes 1 and $\mathbf{2}$ were found to exhibit moderate inhibitory effects on elastase release by human neutrophils.
\end{abstract}

Keywords: excavatoid; briarane; octocoral; Briareum excavatum; human neutrophil

\section{Introduction}

In our continuing research on chemical constituents of marine invertebrates collected in Taiwan waters, a series of interesting and complex briarane-type diterpenoid derivatives (3,8-cyclized 
cembranoids), have been isolated from the octocorals belonging to the genus Briareum [1-21], Ellisella [18,22-25], and Junceella [16,26-38], and the compounds of this type were proven to possess various interesting bioactivities [39-41]. Because of its interesting and potential chemical constituents and a series of new briarane metabolites, including briaexcavatins I-Z [16-20] and excavatoids A-D [21] (Figure 1), the octocoral B. excavatum was transplanted to the National Museum of Marine Biology \& Aquarium (NMMBA), Taiwan. We report herein the isolation, structure determination, and bioactivity of two new briaranes, excavatoids E (1) and F (2) (Figure 2), resulting from further studies on the chemical constituents of cultured B. excavatum. The structures of compounds $\mathbf{1}$ and 2 were established by extensive spectroscopic methods and these two metabolites have displayed moderate inhibitory effects on elastase release by human neutrophils.

Figure 1. The Structures of Excavatoids A-D.

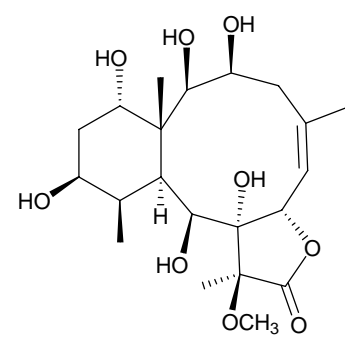

Excavatoid A

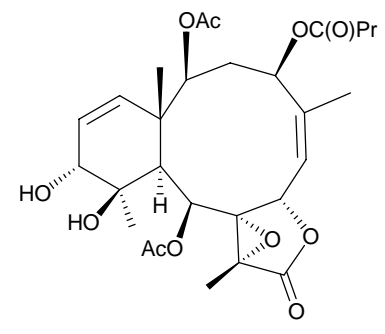

B

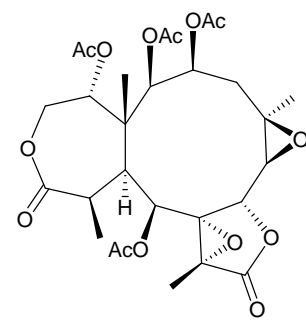

$\mathrm{C}$

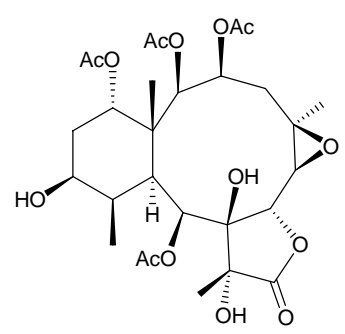

$\mathrm{D}$

Figure 2. The Structures of Excavatoids E (1) and F (2).

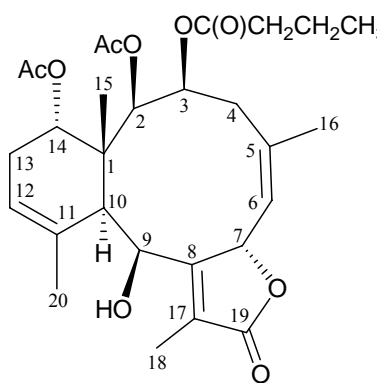

1

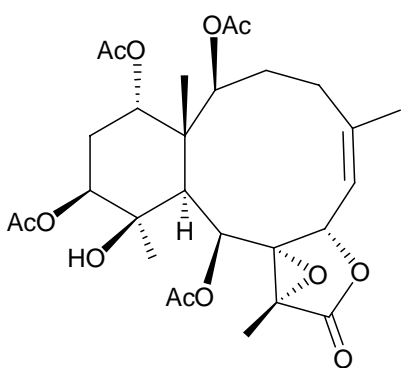

2

\section{Results and Discussion}

Excavatoid E (1) was obtained as a white powder and the molecular formula of $\mathbf{1}$ was determined to be $\mathrm{C}_{28} \mathrm{H}_{38} \mathrm{O}_{9}$ by analysis of ${ }^{13} \mathrm{C}$ - and ${ }^{1} \mathrm{H}-\mathrm{NMR}$ data, in conjunction with DEPT results (Table 1); this conclusion was further confirmed by HRESIMS with $\mathrm{m} / \mathrm{z} 541.2415$ (calcd. for $\mathrm{C}_{28} \mathrm{H}_{38} \mathrm{O}_{9} \mathrm{Na}, 541.2413$ ). This showed that 1 contained 10 degrees of unsaturation. Comparison of the ${ }^{1} \mathrm{H}$ and DEPT data with the molecular formula indicated that there must be an exchangeable proton, requiring the presence of a hydroxy group, and this deduction was supported by a broad band in the IR spectrum at $3,463 \mathrm{~cm}^{-1}$. The IR absorptions of 1 also showed the presence of $\alpha, \beta$-unsaturated $\gamma$-lactone $\left(1,743 \mathrm{~cm}^{-1}\right)$ and ester $\left(1,740 \mathrm{~cm}^{-1}\right)$ groups. From the ${ }^{13} \mathrm{C}-\mathrm{NMR}$ spectrum (Table 1), compound $\mathbf{1}$ was found to possess an $n$-butyryloxy group $\left(\delta_{\mathrm{C}} 13.6, \mathrm{q} ; 18.0, \mathrm{t} ; 35.9, \mathrm{t} ; 172.3, \mathrm{~s}\right)$; two acetoxy groups $\left(\delta_{\mathrm{C}} 21.2, \mathrm{q} ; 20.9\right.$, q; 
$170.4, \mathrm{~s} ; 169.1, \mathrm{~s})$, a $\gamma$-lactone moiety $\left(\delta_{\mathrm{C}} 173.9, \mathrm{~s}, \mathrm{C}-19\right)$, a tetrasubstituted olefin $\left(\delta_{\mathrm{C}} 160.8, \mathrm{~s}, \mathrm{C}-8\right.$; 127.6, s, C-17), and two disubstituted olefins $\left(\delta_{\mathrm{C}} 141.9, \mathrm{~s}, \mathrm{C}-5 ; 123.9, \mathrm{~d}, \mathrm{CH}-6 ; 130.5, \mathrm{~s}, \mathrm{C}-11 ; 123.4\right.$, $\mathrm{d}, \mathrm{CH}-12)$. Thus, from the above data, seven degrees of unsaturation were accounted for, and compound 1 must be tricyclic.

Table 1. ${ }^{1} \mathrm{H}$ and ${ }^{13} \mathrm{C}$-NMR data for Diterpenoids 1 and 2.

\begin{tabular}{|c|c|c|c|c|}
\hline \multirow[b]{2}{*}{ Position } & \multicolumn{2}{|c|}{1} & \multicolumn{2}{|l|}{2} \\
\hline & ${ }^{1} \mathbf{H}^{a}$ & ${ }^{13} C^{b}$ & ${ }^{1} \mathbf{H}^{a}$ & ${ }^{13} C^{b}$ \\
\hline 1 & & $41.7(\mathrm{~s})^{d}$ & & $46.3(\mathrm{~s})$ \\
\hline 2 & $5.45 \mathrm{~d}(2.4)^{c}$ & 74.9 (d) & $5.03 \mathrm{~d}(7.2)$ & 75.3 (d) \\
\hline $3 \alpha$ & $4.98 \mathrm{dd}(6.0,2.4)$ & $72.2(d)$ & $1.69 \mathrm{~m}$ & $32.5(\mathrm{t})$ \\
\hline$\beta$ & & & 2.65 ddd $(15.6,15.6,6.0)$ & \\
\hline $4 \alpha$ & $2.04 \mathrm{~d}(15.6)$ & $34.4(\mathrm{t})$ & $1.97 \mathrm{~m}$ & $28.7(\mathrm{t})$ \\
\hline$\beta$ & $3.46 \mathrm{dd}(15.6,6.0)$ & & $2.50 \mathrm{~m}$ & \\
\hline 5 & & 141.9 (s) & & $146.2(\mathrm{~s})$ \\
\hline 6 & $5.21 \mathrm{~d}(8.8)$ & $123.9(\mathrm{~d})$ & $5.25 \mathrm{~d}(9.2)$ & 117.6 (d) \\
\hline 7 & $6.07 \mathrm{~d}(8.8)$ & $79.2(\mathrm{~d})$ & $5.32 \mathrm{~d}(9.2)$ & 74.9 (d) \\
\hline 8 & & $160.8(\mathrm{~s})$ & & $70.6(\mathrm{~s})$ \\
\hline 9 & 4.98 br s & $68.4(\mathrm{~d})$ & $5.86 \mathrm{~d}(2.0)$ & $67.8(d)$ \\
\hline 10 & $3.25 \mathrm{br} \mathrm{s}$ & 45.2 (d) & $2.20 \mathrm{~d}(2.0)$ & 47.8 (d) \\
\hline 11 & & $130.5 \quad(\mathrm{~s})$ & & 75.7 (s) \\
\hline 12 & 5.58 br s & 123.4 (d) & $4.90 \mathrm{dd}(11.6,5.2)$ & 73.1 (d) \\
\hline $13 \alpha$ & $2.15 \mathrm{~m}$ & $28.0(\mathrm{t})$ & $1.89-1.97 \mathrm{~m}(2 \mathrm{H})$ & $25.6(t)$ \\
\hline$\beta$ & 2.57 br d (18.4) & & & \\
\hline 14 & $5.08 \mathrm{dd}(6.0,6.0)$ & $75.6(d)$ & $4.87 \mathrm{dd}(4.8,2.0)$ & $75.6(d)$ \\
\hline 15 & $1.36 \mathrm{~s}$ & 16.7 (q) & $1.30 \mathrm{~s}$ & $15.6(q)$ \\
\hline 16 & $1.85 \mathrm{~s}$ & $23.0(q)$ & $2.02 \mathrm{~s}$ & $27.0(q)$ \\
\hline 17 & & $127.6(\mathrm{~s})$ & & $64.5(\mathrm{~s})$ \\
\hline 18 & $2.01 \mathrm{~s}$ & $10.2(q)$ & $1.73 \mathrm{~s}$ & $10.3(q)$ \\
\hline 19 & & 173.9 (s) & & $170.9(\mathrm{~s})$ \\
\hline 20 & $1.64 \mathrm{~s}$ & $22.1(q)$ & $1.24 \mathrm{~s}$ & 27.9 (q) \\
\hline 2-OAc & & $169.1 \quad(\mathrm{~s})$ & & $170.5(\mathrm{~s})$ \\
\hline & $2.12 \mathrm{~s}$ & 20.9 (q) & $2.00 \mathrm{~s}$ & $21.3(q)$ \\
\hline 9-OAc & & & & $168.1(\mathrm{~s})$ \\
\hline & & & $2.19 \mathrm{~s}$ & $21.5(q)$ \\
\hline 12-OAc & & & & $169.5(\mathrm{~s})$ \\
\hline & & & $2.07 \mathrm{~s}$ & $21.1(q)$ \\
\hline 14-OAc & & $170.4(\mathrm{~s})$ & & $170.6(\mathrm{~s})$ \\
\hline & $1.99 \mathrm{~s}$ & $21.2(q)$ & $2.05 \mathrm{~s}$ & $21.3(q)$ \\
\hline 3-OCOPr & & $172.3(\mathrm{~s})$ & & \\
\hline & $2.22 \mathrm{t}(7.6)$ & $35.9(\mathrm{t})$ & & \\
\hline & $1.61 \mathrm{~m}$ & $18.0(\mathrm{t})$ & & \\
\hline & $0.94 \mathrm{t}(7.6)$ & $13.6(q)$ & & \\
\hline
\end{tabular}

${ }^{a}$ Spectra were recorded at $400 \mathrm{MHz}$ at $25{ }^{\circ} \mathrm{C} .{ }^{b}$ Spectra were recorded at $100 \mathrm{MHz}$ at $25{ }^{\circ} \mathrm{C} .{ }^{c} J$ values (in $\mathrm{Hz}$ ) in parentheses. ${ }^{d}$ Multiplicity deduced by DEPT and HMQC spectra and indicated by usual symbols. 
Moreover, a methyl singlet $\left(\delta_{\mathrm{H}} 1.36,3 \mathrm{H}, \mathrm{s}, \mathrm{H}_{3}-15\right)$, three vinyl methyls $\left(\delta_{\mathrm{H}} 2.01,3 \mathrm{H}, \mathrm{s}, \mathrm{H}_{3}-18 ; 1.85\right.$, $\left.3 \mathrm{H}, \mathrm{s}, \mathrm{H}_{3}-16 ; 1.64,3 \mathrm{H}, \mathrm{s}, \mathrm{H}_{3}-20\right)$, two pairs of methylene protons $\left(\delta_{\mathrm{H}} 3.46,1 \mathrm{H}, \mathrm{dd}, J=15.6,6.0 \mathrm{~Hz}\right.$; $2.04,1 \mathrm{H}, \mathrm{d}, J=15.6 \mathrm{~Hz}, \mathrm{H}_{2}-4 ; 2.57,1 \mathrm{H}$, br d, $J=18.4 \mathrm{~Hz} ; 2.15,1 \mathrm{H}, \mathrm{m}, \mathrm{H}_{2}-13$ ), an aliphatic methine proton $\left(\delta_{\mathrm{H}} 3.25,1 \mathrm{H}, \mathrm{br} \mathrm{s}, \mathrm{H}-10\right)$, five oxymethine protons $\left(\delta_{\mathrm{H}} 6.07,1 \mathrm{H}, \mathrm{d}, J=8.8 \mathrm{~Hz}, \mathrm{H}-7 ; 5.45,1 \mathrm{H}, \mathrm{d}\right.$, $J=2.4 \mathrm{~Hz}, \mathrm{H}-2 ; 5.08,1 \mathrm{H}, \mathrm{dd}, J=6.0,6.0 \mathrm{~Hz}, \mathrm{H}-14 ; 4.98,1 \mathrm{H}$, br s, H-9; 4.98, 1H, dd, $J=6.0,2.4 \mathrm{~Hz}$, $\mathrm{H}-3)$, two olefin protons $\left(\delta_{\mathrm{H}} 5.58,1 \mathrm{H}\right.$, br s, H-12; $\left.5.21,1 \mathrm{H}, \mathrm{d}, J=8.8 \mathrm{~Hz}, \mathrm{H}-6\right)$, and two acetyl methyls $\left(\delta_{\mathrm{H}} 2.12,3 \mathrm{H}, \mathrm{s} ; 1.99,3 \mathrm{H}, \mathrm{s}\right)$ were observed in the ${ }^{1} \mathrm{H}$-NMR spectrum of $\mathbf{1}$. An $n$-butyryl group $\left(\delta_{\mathrm{H}} 0.94\right.$, $3 \mathrm{H}, \mathrm{t}, J=7.6 \mathrm{~Hz} ; 1.61,2 \mathrm{H}, \mathrm{m} ; 2.22,2 \mathrm{H}, \mathrm{t}, J=7.6 \mathrm{~Hz}$ ) was also observed in the ${ }^{1} \mathrm{H}-\mathrm{NMR}$ spectrum and further confirmed by the ${ }^{1} \mathrm{H}-{ }^{1} \mathrm{H}$ COSY correlations and coupling constant analysis.

Table 2. The ${ }^{1} \mathrm{H}-{ }^{1} \mathrm{H}$ COSY and HMBC $(\mathrm{H} \rightarrow \mathrm{C})$ Correlations for Diterpenoids $\mathbf{1}$ and 2.

\begin{tabular}{|c|c|c|c|c|}
\hline \multirow{2}{*}{ Position } & \multicolumn{2}{|r|}{1} & \multicolumn{2}{|r|}{2} \\
\hline & ${ }^{1} \mathrm{H}-{ }^{1} \mathrm{H} \mathrm{COSY}$ & HMBC & ${ }^{1}{ }^{1}-{ }^{1} H$ COSY & HMBC \\
\hline $\mathrm{H}-2$ & H-3 & $\begin{array}{l}\mathrm{C}-1,-3,-4,-14,-15, \\
\text { acetate carbonyl }\end{array}$ & $\mathrm{H}_{2}-3$ & $\begin{array}{l}\mathrm{C}-1,-3,-4,-10,-14,-15, \\
\text { acetate carbonyl }\end{array}$ \\
\hline $\mathrm{H}-3$ & $\mathrm{H}-2, \mathrm{H}_{2}-4$ & $\mathrm{C}-1$ & $\mathrm{H}-2, \mathrm{H}_{2}-4$ & $\mathrm{C}-1,-4$ \\
\hline $\mathrm{H}-4$ & $\mathrm{H}-3$ & $C-3,-5,-6,-16$ & $\mathrm{H}_{2}-3, \mathrm{H}-6$ & $C-5,-6$ \\
\hline H-6 & $\mathrm{H}-7, \mathrm{H}_{3}-16$ & $C-4,-16$ & $\mathrm{H}-4, \mathrm{H}-7, \mathrm{H}_{3}-16$ & C-4 \\
\hline $\mathrm{H}-7$ & H-6 & $C-5,-6,-8$ & H-6 & $C-5,-6,-19$ \\
\hline H-9 & $\mathrm{H}-10$ & $C-1,-8$ & $\mathrm{H}-10$ & $\begin{array}{l}\mathrm{C}-1,-7,-8,-10,-17 \text {, } \\
\text { acetate carbonyl }\end{array}$ \\
\hline $\mathrm{H}-10$ & H-9 & C-9, -11 & H-9 & $C-1,-2,-8,-9,-11,-14,-15$ \\
\hline $\mathrm{H}-12$ & $\mathrm{H}_{2}-13, \mathrm{H}_{3}-20$ & n.o. ${ }^{a}$ & $\mathrm{H}_{2}-13$ & acetate carbonyl \\
\hline $\mathrm{H}-13$ & H-12, H-14 & n.o. & $\mathrm{H}-12, \mathrm{H}-14$ & $\mathrm{C}-1,-11,-14$ \\
\hline $\mathrm{H}-14$ & $\mathrm{H}_{2}-13$ & $\begin{array}{l}\mathrm{C}-1,-2,-13,-15, \\
\text { acetate carbonyl }\end{array}$ & $\mathrm{H}_{2}-13$ & C-10, acetate carbonyl \\
\hline $\mathrm{H}-15$ & & $C-1,-2,-10,-14$ & & $C-1,-2,-14$ \\
\hline $\mathrm{H}-16$ & H-6 & $C-4,-5,-6$ & H-6 & $C-4,-5,-6$ \\
\hline $\mathrm{H}-18$ & & C-8, $-17,-19$ & & C- $8,-17,-19$ \\
\hline $\mathrm{H}-20$ & H-12 & $C-10,-11,-12$ & & $C-10,-11,-12$ \\
\hline
\end{tabular}

The gross structure of $\mathbf{1}$ was elucidated with the assistance of $2 \mathrm{D}$ NMR studies. From the ${ }^{1} \mathrm{H}-{ }^{1} \mathrm{H}$ COSY experiment of $\mathbf{1}$ (Table 2), it was possible to establish the separate spin systems that map out the proton sequences from $\mathrm{H}-2 / 3 / 4, \mathrm{H}-6 / 7$, and $\mathrm{H}-9 / 10$. These data, together with the HMBC correlations between H-2/C-1, -3, -4; H-3/C-1; H2-4/C-3, -5, -6; H-6/C-4; H-7/C-5, -6, -8; H-9/C-1, -8; and $\mathrm{H}-10 / \mathrm{C}-9$, established the connectivity from $\mathrm{C}-1$ to $\mathrm{C}-10$ in the 10 -membered ring (Table 2). The vinyl methyl groups attached at C-5 and C-11 were confirmed by the HMBC correlations between $\mathrm{H}_{3}-16 / \mathrm{C}-4,-5$, -6 ; and $\mathrm{H}_{3}-20 / \mathrm{C}-10,-11,-12$, and further supported by the allylic couplings between $\mathrm{H}-6 / \mathrm{H}_{3}-16$ and $\mathrm{H}-12 / \mathrm{H}_{3}-20$, respectively. The vinyl methyl group attached at $\mathrm{C}-17$ was also established by the HMBC correlations between $\mathrm{H}_{3}-18$ and $\mathrm{C}-8,-17,-19$. The methylcyclohexene ring, which is fused to the 10 -membered ring at $\mathrm{C}-1$ and $\mathrm{C}-10$, was elucidated by the ${ }^{1} \mathrm{H}-{ }^{1} \mathrm{H}$ COSY correlations between $\mathrm{H}-12 / \mathrm{H}_{2}-13 / \mathrm{H}-14$ and by the HMBC correlations between $\mathrm{H}-2 / \mathrm{C}-14$; H-10/C-11; 
$\mathrm{H}-14 / \mathrm{C}-1$, -2 ; and $\mathrm{H}_{3}-20 / \mathrm{C}-10$. The ring junction $\mathrm{C}-15$ methyl group was positioned at $\mathrm{C}-1$ from the HMBC correlations between $\mathrm{H}-2 / \mathrm{C}-15$; $\mathrm{H}-14 / \mathrm{C}-15$; and $\mathrm{H}_{3}-15 / \mathrm{C}-1,-2,-10,-14$. In addition, the HMBC correlations also revealed that two acetates should attach at $\mathrm{C}-2$ and $\mathrm{C}-14$, respectively. The remaining $n$-butyryloxy and hydroxy groups were positioned at C-3 and C-9 as indicated by analysis of ${ }^{1} \mathrm{H}-{ }^{1} \mathrm{H}$ COSY correlations and characteristic NMR signals analysis, although no HMBC correlation was observed between $\mathrm{H}-3$ and the $n$-butyrate carbonyl.

Based on previous studies, all naturally occurring briarane-type diterpenoids have the C-15 methyl group trans to $\mathrm{H}-10$, and these two groups are assigned as $\beta$ - and $\alpha$-oriented, respectively, as shown in most briarane derivatives [42-44]. The relative stereochemistry of 1 was established from a NOESY experiment (Figure 3), in which the NOE correlations of $\mathrm{H}-10$ with $\mathrm{H}-3$ and H-9; and H-3 with H-2, indicated that these protons are situated on the same face and were assigned as $\alpha$ protons since the $\mathrm{C}$-15 methyl is the $\beta$-substituent at C-1. $\mathrm{H}-14$ was found to exhibit a correlation with $\mathrm{H}_{3}-15$ but not with $\mathrm{H}-10$, revealing the $\beta$-orientation of this proton. One of the $\mathrm{C}-4$ methylene protons $\left(\delta_{\mathrm{H}} 3.46\right)$ exhibited a correlation with $\mathrm{H}_{3}-15$ and was assigned as $\mathrm{H}-4 \beta$, while the other was denoted as $\mathrm{H}-4 \alpha\left(\delta_{\mathrm{H}} 2.04\right)$. A correlation observed between $\mathrm{H}-4 \beta$ and $\mathrm{H}-7$, reflected the $\beta$-orientation of $\mathrm{H}-7$. The NOESY spectrum showed correlations of $\mathrm{H}-6 / \mathrm{H}_{3}-16$ and $\mathrm{H}-12 / \mathrm{H}_{3}-20$, revealing the $Z$ geometry of C-5/6 and C-11/12 double bonds in 1.

Figure 3. Selected NOE Correlations of 1.

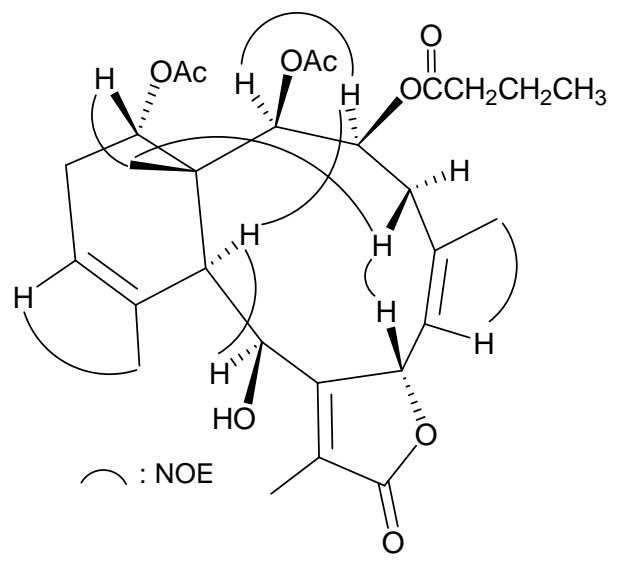

The molecular formula of excavatoid $\mathrm{F}$ (2) was determined as $\mathrm{C}_{28} \mathrm{H}_{38} \mathrm{O}_{12}$ by its HRESIMS ( $\mathrm{m} / \mathrm{z}$ 589.2257, calcd. for $\mathrm{C}_{28} \mathrm{H}_{38} \mathrm{O}_{12} \mathrm{Na}, 589.2261$ ). The IR spectrum showed bands at 3,487, 1,779, and $1,737 \mathrm{~cm}^{-1}$, consistent with the presence in 2 of hydroxy, $\gamma$-lactone, and ester groups. From the ${ }^{13} \mathrm{C}-\mathrm{NMR}$ data of 2 (Table 1), a trisubstituted olefin was deduced from the signals of two carbons at $\delta_{\mathrm{C}} 146.2$ (s, C-5) and 117.6 (d, CH-6). A methyl-containing tetrasubstituted epoxy group was confirmed from the signals of two quaternary oxygenated carbons at $\delta_{\mathrm{C}} 70.6$ (s, C-8) and 64.5 (s, $\mathrm{C}-17)$, and from the chemical shifts of a tertiary methyl group $\left(\delta_{\mathrm{H}} 1.73,3 \mathrm{H}, \mathrm{s}, \mathrm{H}_{3}-18 ; \delta_{\mathrm{C}} 10.3, \mathrm{q}\right.$, $\mathrm{CH}_{3}$-18) (Table 1). Moreover, five carbonyl resonances appeared at $\delta_{\mathrm{C}} 170.9$ (s, C-19), 170.6, 170.5, 169.5, and $168.1(4 \times \mathrm{s}$, ester carbonyls), confirming the presence of a $\gamma$-lactone and four esters in 2 . All the esters were identified as acetates by the presence of methyl resonances in the ${ }^{1} \mathrm{H}-\mathrm{NMR}$ spectrum at $\delta_{\mathrm{H}} 2.19,2.07,2.05$, and $2.00($ each $3 \mathrm{H} \times \mathrm{s})$. 
The planar structure of 2 was determined mainly by 2D NMR studies. The coupling information in the ${ }^{1} \mathrm{H}-{ }^{1} \mathrm{H}$ COSY spectrum of 2 enabled identification of the proton sequences $\mathrm{H}-2 / 3 / 4, \mathrm{H}-4 / 6$ (by allylic coupling), H-6/7, H-6/ $\mathrm{H}_{3}-16$ (by allylic coupling), H-9/10, and H-12/13/14 (Table 2). These data, together with the correlations observed in an HMBC experiment of 2 (Table 2), the molecular framework of 2 could be further established. The HMBC correlations also indicated that the acetoxy groups should attach at C-2, $-9,-12$, and C-14. Thus, the remaining hydroxy group has to be positioned at C-11, as indicated by characteristic NMR signal analysis. The relative stereochemistry of 2 was elucidated from the NOE interactions observed in a NOESY experiment (Figure 4). In the NOESY spectrum of 2, correlations were observed between $\mathrm{H}-10$ with $\mathrm{H}-2,-9,-12$, and $\mathrm{H}_{3}-20$, indicating that these protons should be positioned on the $\alpha$ face in $\mathbf{2}$ and Me-20 was positioned on the equatorial direction in the methylcyclohexane ring of 2 . One proton attaching at C-3 $\left(\delta_{\mathrm{H}} 2.65\right)$ was found to exhibit a correlation with $\mathrm{H}_{3}-15$ and was assigned as $\mathrm{H}-3 \beta$ proton. $\mathrm{H}-7$ showed a correlation with $\mathrm{H}-3 \beta$, confirming the $\beta$-orientation for this proton. Furthermore, $\mathrm{H}_{3}-18$ was found to show correlations with $\mathrm{H}-9, \mathrm{H}_{3}-20$, and $\mathrm{H}-7$, and from molecular models, was found to be reasonably closed to H-9, $\mathrm{H}_{3}-20$, and $\mathrm{H}-7$; therefore, $\mathrm{H}_{3}-18$ should be placed on the $\beta$ face in the $\gamma$-lactone ring of 2 . The Z-configuration of the C-5/C-6 double bond was elucidated by an interaction between $\mathrm{H}-6\left(\delta_{\mathrm{H}} 5.25\right)$ and $\mathrm{H}_{3}-16\left(\delta_{\mathrm{H}} 2.02\right)$. On the basis of the above results, the structure of 2 , including the relative configuration, was elucidated.

Figure 4. Selected NOE Correlations of 2.

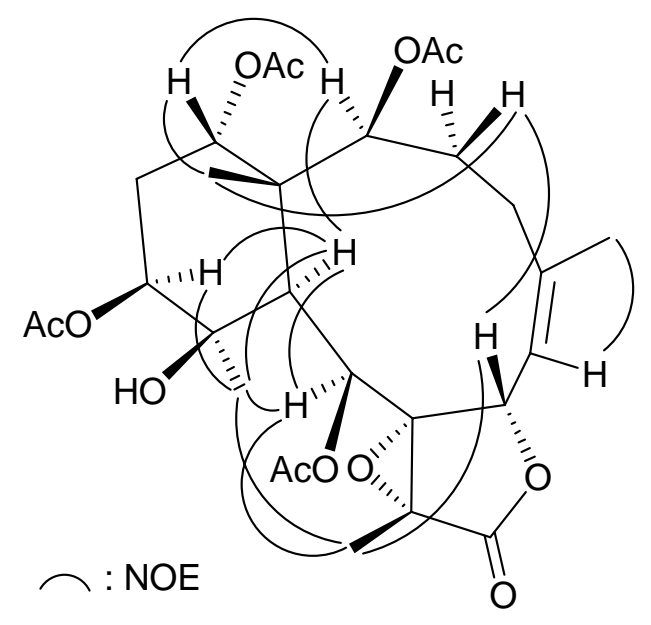

Table 3. Inhibitory Effects of Compounds $\mathbf{1}$ and $\mathbf{2}$ on Elastase Release and Superoxide Anion Generation by Human Neutrophils in Response to fMet-Leu-Phe/Cytochalastin B.

\begin{tabular}{ccc}
\hline & Elastase & Superoxide Anion \\
\cline { 2 - 3 } Compound & Inh.\% & Inh.\% \\
\hline $\mathbf{1}$ & $26.22 \pm 0.50 * * *$ & $12.95 \pm 6.99$ \\
$\mathbf{2}$ & $30.63 \pm 4.68 *$ & $2.57 \pm 1.11$ \\
\hline
\end{tabular}

Percentage of inhibition (Inh.\%) at $10 \mu \mathrm{g} / \mathrm{mL}$ concentration. Results are presented as mean \pm S.E.M. $(n=2-3)$. ${ }^{*} P<0.05,{ }^{* *} P<0.01$, and $* * * P<0.001$ compared with the control value. 
In previous study, several diterpenoid derivatives of potential medical interest were isolated from a cultured gorgonian coral Erythropodium caribaeorum [45]. Because all corals are claimed to be threatened species, we wanted to maintain and culture these interesting specimens as sources of new and interesting natural products in our continuing search for novel substances from marine organisms originally collected in Taiwan waters, in the hope of identifying extracts that exhibit bioactivity. Briaranes 1 and $\mathbf{2}$ displayed moderate inhibitory effects on elastase release by neutrophils, and briarane 1 exhibited weak inhibitory effects on superoxide anion generation by human neutrophils at $10 \mu \mathrm{g} / \mathrm{mL}$, respectively (Table 3). Furthermore, these two compounds were not cytotoxic toward the CCRF-CEM (human T-cell acute lymphoblastic leukemia) and DLD-1 (human colon adenocarcinoma) cells $\left(\mathrm{ED}_{50}>40 \mu \mathrm{g} / \mathrm{mL}\right)$. The possible bioactivity for these two compounds will be further studied if we can obtain enough material from the cultured B. excavatum in the future.

\section{Experimental Section}

\subsection{General Experimental Procedures}

Melting points were determined on a Fargo apparatus and were uncorrected. Optical rotation values were measured with a JASCO P-1010 digital polarimeter at $25^{\circ} \mathrm{C}$. Infrared spectra were obtained on a Varian Digilab FTS 1000 FT-IR spectrometer. The NMR spectra were recorded on a Varian Mercury Plus 400 FT-NMR at $400 \mathrm{MHz}$ for ${ }^{1} \mathrm{H}$ and $100 \mathrm{MHz}$ for ${ }^{13} \mathrm{C}$, in $\mathrm{CDCl}_{3}$, respectively. Proton chemical shifts were referenced to the residual $\mathrm{CHCl}_{3}$ signal $(\delta 7.26 \mathrm{ppm}) .{ }^{13} \mathrm{C}-\mathrm{NMR}$ spectra were referenced to the center peak of $\mathrm{CDCl}_{3}$ at $\delta 77.1 \mathrm{ppm}$. ESIMS and HRESIMS data were recorded on a Bruker APEX II mass spectrometer. Column chromatography was performed on silica gel (230-400 mesh, Merck, Darmstadt, Germany). TLC was carried out on precoated Kieselgel $60 \mathrm{~F}_{254}(0.25 \mathrm{~mm}$, Merck) and spots were visualized by spraying with $10 \% \mathrm{H}_{2} \mathrm{SO}_{4}$ solution followed by heating. HPLC was performed using a system comprised of a Hitachi L-7100 pump, a Hitachi photodiode array detector L-7455, and a Rheodyne 7725 injection port. A semi-preparative reverse phase column (Hibar $250 \times 10$ mm, LiChrospher 100 RP-18e, $5 \mu \mathrm{m}$, Merck) was used for HPLC.

\subsection{Animal Material}

Specimens of the octocoral Briareum excavatum were collected and transplanted to a 0.6-ton cultivating tank located in the NMMBA, Taiwan, in December 2003, and the material for this research work was collected from the tank in December 2006. This organism was identified by comparison with previous descriptions [46-48]. A voucher specimen was deposited in the National Museum of Marine Biology \& Aquarium, Taiwan (NMMBA-CSC-001).

\subsection{Extraction and Isolation}

The freeze-dried and minced material of B. excavatum (wet weight $672 \mathrm{~g}$, dry weight $270 \mathrm{~g}$ ) was extracted with a mixture of $\mathrm{MeOH}$ and $\mathrm{CH}_{2} \mathrm{Cl}_{2}$ (1:1) at room temperature. The residue was partitioned between EtOAc and $\mathrm{H}_{2} \mathrm{O}$. The EtOAc layer was separated on Sephadex LH-20 and eluted using 
$\mathrm{MeOH} / \mathrm{CH}_{2} \mathrm{Cl}_{2}$ (2:1) to yield three fractions A-C. Fraction $\mathrm{C}$ was separated on silica gel and eluted using hexane/EtOAc (stepwise, 20:1-pure EtOAc) to yield fractions 1-9. Fraction $\mathrm{C} 7$ was separated by reverse phase $\mathrm{HPLC}$, using the mixtures of $\mathrm{MeOH}, \mathrm{CH}_{3} \mathrm{CN}$, and $\mathrm{H}_{2} \mathrm{O}$ to afford briaranes 1 (2.9 mg, 65/1/34) and 2 (1.2 mg, 62/1/37).

Excavatoid E (1): white powder; mp $192-193{ }^{\circ} \mathrm{C} ;[\alpha]_{\mathrm{D}}^{25}+2\left(\right.$ c $\left.0.15, \mathrm{CHCl}_{3}\right)$; IR (neat) $v_{\max } 3,463$, 1,743, 1,737 $\mathrm{cm}^{-1} ;{ }^{13} \mathrm{C}-\mathrm{NMR}\left(\mathrm{CDCl}_{3}, 100 \mathrm{MHz}\right)$ and ${ }^{1} \mathrm{H}-\mathrm{NMR}\left(\mathrm{CDCl}_{3}, 400 \mathrm{MHz}\right)$ data, see Table 1; ESIMS m/z $541(\mathrm{M}+\mathrm{Na})^{+}$; HRESIMS m/z 541.2415 (calcd. for $\mathrm{C}_{28} \mathrm{H}_{38} \mathrm{O}_{9} \mathrm{Na}$, 541.2413).

Excavatoid F (2): white powder; mp $164-165{ }^{\circ} \mathrm{C}$; $[\alpha]_{\mathrm{D}}^{25}-16\left(c 0.06, \mathrm{CHCl}_{3}\right)$; IR (neat) $v_{\max } 3,487$, 1,779, 1,737 $\mathrm{cm}^{-1} ;{ }^{13} \mathrm{C}-\mathrm{NMR}\left(\mathrm{CDCl}_{3}, 100 \mathrm{MHz}\right)$ and ${ }^{1} \mathrm{H}-\mathrm{NMR}\left(\mathrm{CDCl}_{3}, 400 \mathrm{MHz}\right)$ data, see Table 1; ESIMS m/z $589(\mathrm{M}+\mathrm{Na})^{+}$; HRESIMS m/z 589.2257 (calcd. for $\mathrm{C}_{28} \mathrm{H}_{38} \mathrm{O}_{12} \mathrm{Na}, 589.2261$ ).

\subsection{Human Neutrophil Superoxide Anion Generation and Elastase Release}

Human neutrophils were obtained by means of dextran sedimentation and Ficoll centrifugation. Superoxide generation was carried out according to the procedures described previously $[49,50]$. Briefly, superoxide anion production was assayed by monitoring the superoxide dismutase-inhibitable reduction of ferricytochrome $c$. Elastase release experiments were performed using MeO-Suc-Ala-AlaPro-Valp-nitroanilide as the elastase substrate.

\section{Acknowledgements}

This study was supported by grants from the NMMBA (Grant No. 981001101); NDHU; APORC, NSYSU; and NSTPBP, National Science Council (NSC 97-2323-B-291-001, 98-2323-B-291-001, and 98-2320-B-291-001), Taiwan, awarded to P.-J. Sung.

\section{References}

1. Sheu, J.-H.; Sung, P.-J.; Huang, L.-H.; Lee, S.-F.; Wu, T.; Chang, B.-Y.; Duh, C.-Y.; Fang, L.-S.; Soong, K.; Lee, T.-J. New cytotoxic briaran diterpenes from the Formosan gorgonian Briareum sp. J. Nat. Prod. 1996, 59, 935-938.

2. Sheu, J.-H.; Sung, P.-J.; Cheng, M.-C.; Liu, H.-Y.; Fang, L.-S.; Duh, C.-Y.; Chiang, M.Y. Novel cytotoxic diterpenes, excavatolides A-E, isolated from the Formosan gorgonian Briareum excavatum. J. Nat. Prod. 1998, 61, 602-608.

3. Sung, P.-J.; Su, J.-H.; Wang, G.-H.; Lin, S.-F.; Duh, C.-Y.; Sheu, J.-H. Excavatolides F-M, new briarane diterpenes from the gorgonian Briareum excavatum. J. Nat. Prod. 1999, 62, 457-463.

4. Sheu, J.-H.; Sung, P.-J.; Su, J.-H.; Wang, G.-H.; Duh, C.-Y.; Shen, Y.-C.; Chiang, M.Y.; Chen, I.-T. Excavatolides U-Z, new briarane diterpenes from the gorgonian Briareum excavatum. J. Nat. Prod. 1999, 62, 1415-1420.

5. Sheu, J.-H.; Sung, P.-J.; Su, J.-H.; Liu, H.-Y.; Duh, C.-Y.; Chiang, M.Y. Briaexcavatolides A-J, new diterpenes from the gorgonian Briareum excavatum. Tetrahedron 1999, 55, 14555-14564.

6. Sung, P.-J.; Su, J.-H.; Duh, C.-Y.; Chiang, M.Y.; Sheu, J.-H. Briaexcavatolides K-N, new briarane diterpenes from the gorgonian Briareum excavatum. J. Nat. Prod. 2001, 64, 318-323. 
7. Wu, S.-L.; Sung, P.-J.; Chiang, M.Y.; Wu, J.-Y.; Sheu, J.-H. New polyoxygenated briarane diterpenoids, briaexcavatolides O-R, from the gorgonian Briareum excavatum. J. Nat. Prod. 2001, 64, 1415-1420.

8. Wu, S.-L.; Sung, P.-J.; Su, J.-H.; Sheu, J.-H. Briaexcavatolides S-V, four new briaranes from a Formosan gorgonian Briareum excavatum. J. Nat. Prod. 2003, 66, 1252-1256.

9. Wu, S.-L.; Sung, P.-J.; Su, J.-H.; Wang, G.-H.; Sheu, J.-H. Briaexcavatolide W, a new diterpenoid from Briareum excavatum. Heterocycles 2004, 63, 895-898.

10. Sung, P.-J.; Hu, W.-P.; Wu, S.-L.; Su, J.-H.; Fang, L.-S.; Wang, J.-J.; Sheu, J.-H. Briaexcavatolides $\mathrm{X}-\mathrm{Z}$, three new briarane-related derivatives from the gorgonian coral Briareum excavatum. Tetrahedron 2004, 60, 8975-8979.

11. Sung, P.-J.; Hu, W.-P.; Fang, L.-S.; Fan, T.-Y.; Wang, J.-J. Briarenol A, a new diterpenoid from a gorgonian Briareum sp. (Briareidae). Nat. Prod. Res. 2005, 19, 689-694.

12. Sung, P.-J.; Chao, C.-H.; Chen, Y.-P.; Su, J.-H.; Hu, W.-P.; Sheu, J.-H. Briaexcavatins A and B, novel briaranes from the octocoral Briareum excavatum. Tetrahedron Lett. 2006, 47, 167-170.

13. Sung, P.-J.; Chen, Y.-P.; Hwang, T.-L.; Hu, W.-P.; Fang, L.-S.; Wu, Y.-C.; Li, J.-J.; Sheu, J.-H. Briaexcavatins $\mathrm{C}-\mathrm{F}$, four new briarane-related diterpenoids from the Formosan octocoral Briareum excavatum (Briareidae). Tetrahedron 2006, 62, 5686-5691.

14. Chen, Y.-P.; Wu, S.-L.; Su, J.-H.; Lin, M.-R.; Hu, W.-P.; Hwang, T.-L.; Sheu, J.-H.; Fan, T.-Y.; Fang, L.-S.; Sung, P.-J. Briaexcavatins G and H, two new briaranes from the octocoral Briareum excavatum. Bull. Chem. Soc. Jpn. 2006, 79, 1900-1905.

15. Su, J.-H.; Sung, P.-J.; Kuo, Y.-H.; Hsu, C.-H.; Sheu, J.-H. Briarenolides A-C, briarane diterpenoids from the gorgonian coral Briareum sp. Tetrahedron 2007, 63, 8282-8285.

16. Sung, P.-J.; Lin, M.-R.; Su, Y.-D.; Chiang, M. Y.; Hu, W.-P.; Su, J.-H.; Cheng, M.-C.; Hwang, T.-L.; Sheu, J.-H. New briaranes from the octocorals Briareum excavatum (Briareidae) and Junceella fragilis (Ellisellidae). Tetrahedron 2008, 64, 2596-2604.

17. Sung, P.-J.; Lin, M.-R.; Hwang, T.-L.; Fan, T.-Y.; Su, W.-C.; Ho, C.-C.; Fang, L.-S.; Wang, W.-H. Briaexcavatins M-P, four new briarane-related diterpenoids from cultured octocoral Briareum excavatum (Briareidae). Chem. Pharm. Bull. 2008, 56, 930-935.

18. Hwang, T.-L.; Lin, M.-R.; Tsai, W.-T.; Yeh, H.-C.; Hu, W.-P.; Sheu, J.-H.; Sung, P.-J. New polyoxygenated briaranes from octocorals Briareum excavatum and Ellisella robusta. Bull. Chem. Soc. Jpn. 2008, 81, 1638-1646.

19. Sung, P.-J.; Lin, M.-R.; Chiang, M.Y. The structure and absolute stereochemistry of briaexcavatin $\mathrm{U}$, a new chlorinated briarane from a cultured octocoral Briareum excavatum. Chem. Lett. 2009, 38, 154-155.

20. Sung, P.-J.; Lin, M.-R.; Chiang, M.Y.; Hwang, T.-L. Briaexcavatins V-Z, discovery of new briaranes from a cultured octocoral Briareum excavatum. Bull. Chem. Soc. Jpn. 2009, 82, 987-996.

21. Sung, P.-J.; Su, Y.-D.; Li, G.-Y.; Chiang, M. Y.; Lin, M.-R.; Huang, I.-C.; Li, J.-J.; Fang, L.-S.; Wang, W.-H. Excavatoids A-D, new polyoxygenated briaranes from the octocoral Briareum excavatum. Tetrahedron 2009, 65, 6918-6924. 
22. Sung, P.-J.; Tsai, W.-T.; Chiang, M.Y.; Su, Y.-M.; Kuo, J. Robustolides A-C, three new briaranetype diterpenoids from the female gorgonian coral Ellisella robusta (Ellisellidae). Tetrahedron 2007, 63, 7582-7588.

23. Su, Y.-M.; Fan, T.-Y.; Sung, P.-J. 11,20-Epoxybriaranes from the gorgonian coral Ellisella robusta (Ellisellidae). Nat. Prod. Res. 2007, 21, 1085-1090.

24. Sung, P.-J.; Chiang, M.Y.; Tsai, W.-T.; Su, J.-H.; Su, Y.-M.; Wu, Y.-C. Chlorinated briarane-type diterpenoids from the gorgonian coral Ellisella robusta (Ellisellidae). Tetrahedron 2007, 63, $12860-12865$.

25. Sung, P.-J.; Tsai, W.-T.; Lin, M.-R.; Su, Y.-D.; Pai, C.-H.; Chung, H.-M.; Su, J.-H.; Chiang, M. Y. Robustolides $\mathrm{H}$ and I, chlorinated briaranes from the gorgonian coral Ellisella robusta (Ellisellidae). Chem. Lett. 2008, 37, 88-89.

26. Sung, P.-J.; Wu, S.-L.; Fang, H.-J.; Chiang, M. Y.; Wu, J.-Y.; Fang, L.-S.; Sheu, J.-H. Junceellolides E-G, new briarane diterpenes from the West Pacific Ocean gorgonian Junceella fragilis. J. Nat. Prod. 2000, 63, 1483-1487.

27. Sung, P.-J.; Fan, T.-Y. 9-O-Deacetylumbraculolide A, a new diterpenoid from the gorgonian Junceella fragilis. Heterocycles 2003, 60, 1199-1202.

28. Sung, P.-J.; Fan, T.-Y.; Fang, L.-S.; Sheu, J.-H.; Wu, S.-L.; Wang, G.-H.; Lin, M.-R. Juncin N, a new briarane-type diterpenoid from the gorgonian coral Junceella juncea. Heterocycles 2003, 61, 587-592.

29. Sung, P.-J.; Fan, T.-Y.; Fang, L.-S.; Wu, S.-L.; Li, J.-J.; Chen, M.-C.; Cheng, Y.-M.; Wang, G.-H. Briarane derivatives from the gorgonian coral Junceella fragilis. Chem. Pharm. Bull. 2003, 51, 1429-1431.

30. Sung, P.-J.; Fan, T.-Y.; Chen, M.-C.; Fang, L.-S.; Lin, M.-R.; Chang, P.-C. Junceellin and praelolide, two briaranes from the gorgonian corals Junceella fragilis and Junceella juncea (Ellisellidae). Biochem. Syst. Ecol. 2004, 32, 111-113.

31. Sung, P.-J.; Lin, M.-R.; Fang, L.-S. Briarane diterpenoids from the Formosan gorgonian coral Junceella fragilis. Chem. Pharm. Bull. 2004, 52, 1504-1506.

32. Sung, P.-J.; Lin, M.-R.; Chen, W.-C.; Fang, L.-S.; Lu, C.-K.; Sheu, J.-H. Fragilide A, a novel diterpenoid from Junceella fragilis. Bull. Chem. Soc. Jpn. 2004, 77, 1229-1230.

33. Sheu, J.-H.; Chen, Y.-P.; Hwang, T.-L.; Chiang, M. Y.; Fang, L.-S.; Sung, P.-J. Junceellolides J-L, 11,20-epoxybriaranes from the gorgonian coral Junceella fragilis. J. Nat. Prod. 2006, 69, 269-273.

34. Sung, P.-J.; Chen, Y.-P.; Su, Y.-M.; Hwang, T.-L.; Hu, W.-P.; Fan, T.-Y.; Wang, W.-H. Fragilide B, a novel briarane-type diterpenoid with a s-cis diene moiety. Bull. Chem. Soc. Jpn. 2007, 80, 1205-1207.

35. Sung, P.-J.; Pai, C.-H.; Su, Y.-D.; Hwang, T.-L.; Kuo, F.-W.; Fan, T.-Y.; Li, J.-J. New 8-hydroxybriarane diterpenoids from the gorgonians Junceella juncea and Junceella fragilis (Ellisellidae). Tetrahedron 2008, 64, 4224-4232 (corrigendum in Tetrahedron 2008, 64, 9150).

36. Sung, P.-J.; Pai, C.-H.; Hwang, T.-L.; Fan, T.-Y.; Su, J.-H.; Chen, J.-J.; Fang, L.-S.; Wang, W.-H.; Sheu, J.-H. Junceols D-H, new polyoxygenated briaranes from sea whip gorgonian coral Junceella juncea (Ellisellidae). Chem. Pharm. Bull. 2008, 56, 1276-1281. 
37. Sung, P.-J.; Li, G.-Y.; Chen, Y.-P.; Huang, I.-C.; Chen, B.-Y.; Wang, S.-H.; Huang, S.-K. Fragilide E, a novel chlorinated 20-acetoxybriarane from the gorgonian coral Junceella fragilis. Chem. Lett. 2009, 38, 454-455.

38. Sung, P.-J.; Wang, S.-H.; Chiang, M.Y.; Su, Y.-D.; Chang, Y.-C.; Hu, W.-P.; Tai, C.-Y.; Liu, C.-Y. Discovery of new chlorinated briaranes from Junceella fragilis. Bull. Chem. Soc. Jpn. 2009, 82, in press.

39. Blunt, J.W.; Copp, B.R.; Hu, W.-P.; Munro, M.H.G.; Northcote, P.T.; Prinsep, M.R. Marine natural products. Nat. Prod. Rep. 2009, 26, 170-244, and references cited therein.

40. Berrue, F.; Kerr, R.G. Diterpenes from gorgonian corals. Nat. Prod. Rep. 2009, 26, 681-710, and references cited therein.

41. Hanson, J.R. Diterpenoids. Nat. Prod. Rep. 2009, 26, 1156-1171, and references cited therein.

42. Sung, P.-J.; Sheu, J.-H.; Xu, J.-P. Survey of briarane-type diterpenoids of marine origin. Heterocycles 2002, 57, 535-579.

43. Sung, P.-J.; Chang, P.-C.; Fang, L.-S.; Sheu, J.-H.; Chen, W.-C.; Chen, Y.-P.; Lin, M-R. Survey of briarane-type diterpenoids-Part II. Heterocycles 2005, 65, 195-204.

44. Sung, P.-J.; Chang, P.-C.; Fang, L.-S.; Sheu, J.-H.; Chen, W.-C.; Chen, Y.-P.; Lin, M-R. Survey of briarane-type diterpenoids-Part III. Heterocycles 2008, 75, 2627-2648.

45. Taglialatela-Scafati, O.; Deo-Jangra, U.; Campbell, M.; Roberge, M.; Andersen, R.J. Diterpenoids from cultured Erythropodium caribaeorum. Org. Lett. 2002, 4, 4085-4088.

46. Bayer, F.M. Key to the genera of octocorallia exclusive of Pennatulacea (Coelenterata: anthozoa), with diagnoses of new taxa. Proc. Biol. Soc. Wash. 1981, 94, 902-947.

47. Benayahu, Y.; Jeng, M.-S.; Perkol-Finkel, S.; Dai, C.-F. Soft corals (Octocorallia: Alcyonacea) from southern Taiwan. II. Species diversity and distribution patterns. Zool. Stud. 2004, 43, $548-560$.

48. Fabricius, K.; Alderslade, P. Soft Corals and Sea Fans-A comprehensive guide to the tropical shallow-water genera of the Central-West Pacific, the Indian Ocean and the Red Sea, $1^{\text {st }}$ ed.; Australian Institute of Marine Science: Queensland, Australia, 2001; pp. 55, 154-157.

49. Hwang, T.-L.; Li, G.-L.; Lan, Y.-H.; Chia, Y.-C.; Hsieh, P.-W.; Wu, Y.-H.; Wu, Y.-C. Potent inhibitors of superoxide anion production in activated human neutrophils by isopedicin, a bioactive component of the Chinese medicinal herb Fissistigma oldhamii. Free Radic. Biol. Med. 2009, 46, 520-528.

50. Hwang, T.-L.; Su, Y.-C.; Chang, H.-L.; Leu, Y.-L.; Chung, P.-J.; Kuo, L.-M.; Chang, Y.-J. Suppression of superoxide anion and elastase release by $\mathrm{C}_{18}$ unsaturated fatty acids in human neutrophils. J. Lipid Res. 2009, 50, 1395-1408.

Sample Availability: Not available.

(C) 2009 by the authors; licensee Molecular Diversity Preservation International, Basel, Switzerland. This article is an open-access article distributed under the terms and conditions of the Creative Commons Attribution license (http://creativecommons.org/licenses/by/3.0/). 